C. Keller MD,

J. Brimacombe $M B$ CHB FRCA MD*

\title{
The intubating laryngeal mask airway in fresh cadavers $p s$ paralysed anesthetised patients
}

Purpose: To compare the performance of the intubating laryngeal mask airway (ILM) between fresh cadavers and anesthetised patients in terms of ease of insertion, oropharyngeal leak pressure (OLP), in-vivo intracuff pressure, anatomical position (assessed fibreoptically) and ease of fibreoptic-guided intubation.

Methods: Twenty paralysed anesthetised patients and twenty cadavers (6-24 hr post-mortem) were studied. Groups were matched for height, weight and sex. Ease of insertion and ease of fibreoptic-guided intubation (number of insertion attempts and time to successful placement) were recorded. The OLP, in-vivo intracuff pressure and anatomical position (judged fibreoptically) were measured at zero volume and after each additional $10 \mathrm{ml}$ up to $40 \mathrm{ml}$.

Results: There were no differences in ease of insertion or ease of fibreoptic-guided intubation, OLP, in-vivo intracuff pressure or anatomic position between groups.

Conclusions: We conclude that the performance of the ILM is similar for fresh cadavers and paralysed anesthetised patients. This suggests that the fresh cadaver is a suitable model for training and research.

Objectif : Comparer le fonctionnement du masque laryngé d'intubation (MLI) chez des cadavres frais et des patients anesthésiés, en termes de facilité d'insertion, perte de pression oropharyngée (PPO), pression in vivo à l'intérieur du ballonnet, position anatomique (évaluée par fibroscopie) et facilité d'intubation fibroscopique.

Méthode : On a étudié 20 patients insensibilisés sous anesthésie et 20 cadavres (6-24h post mortem). Des groupes ont été formés selon la grandeur, le poids et le sexe. La facilité d'insertion et la facilité d'intubation fibroscopique (le nombre d'essais et le temps nécessaire au positionnement réussi) ont été enregistrées. La PPO, la pression intraballonnet in vivo et la position anatomique (jugée par fibroscopie) ont été mesurées au volume zéro. puis après chaque addition de $10 \mathrm{ml}$, jusqu'à $40 \mathrm{ml}$.

Résultats : II n'y a pas eu de différence intergroupe quant à la facilité d'insertion ou d'intubation fibroscopique, de PPO, de pression intraballonnet in vivo ou de position anatomique.

Conclusion : Le fonctionnement du MLI est similaire chez des cadavres frais et des patients anesthésiés. Le cadavre frais est donc un modèle fiable à utiliser pour la formation et la recherche.

From the Department of Anaesthesia and Intensive Care Medicine, Leopold-Franzens University, 6020, Innsbruck, Austria and Department of Anaesthesia and Intensive Care, Cairns Base Hospital, ${ }^{*}$ The Esplanade, Cairns 4870, Australia. Address correspondence to: Dr. J. Brimacombe, Department of Anaesthesia and Intensive Care, Cairns Base Hospital, The Esplanade, Cairns 4870, Australia. Fax: 61-70-311628; E-mail: 100236,2343@compuserve.com. Accepted for publication July 30, 1999 
$\mathrm{T}$ HE intubating laryngeal mask (ILM) is a new airway device designed to produce better intubation characteristics than the standard laryngeal mask airway (LMA)..$^{1,2}$ It has a probable role in the management of the difficult airway and possibly a role in resuscitation. ${ }^{3}$ Complications associated with misuse of the ILM may be more severe than the LMA because of the rigid airway tube and higher mucosal pressures. ${ }^{4} \mathrm{~A}$ fatal case of esophageal perforation has been reported following difficult insertion in an elderly patient..$^{5}$ Training in ILM usage is critical to safe use, but may be limited by a lack of access to patients. Furthermore, some investigations into major complications such as aspiration, neurovascular trauma and placement in the unstable cervical spine may be inappropriate in patients due to increased risk. The value of cadavers for training and research depends on the degree of similarity between the cadaver model and the anesthetised or unconscious patient. In this study, we compared the performance of the ILM between fresh cadavers and anesthetised patients in terms of ease of insertion, oropharyngeal leak pressure (OLP), in vipo intracuff pressure, anatomical position and ease of fibreoptic-guided intubation.

\section{Methods}

Twenty paralysed anesthetised patients requiring intubation and 20 fresh cadavers (6-24 hr post-mortem) were studied. Research and Ethics committee approval was obtained. All patients, or their relatives, consented to post-mortem research before using the cadavers. All patients undergoing anesthesia gave their informed consent. Anesthetised patients and cadavers were excluded if they were unsuitable for the ILM, or had oro-pharyngo-laryngeal pathology, or a known difficult airway. Groups were matched for height, weight and sex. Anesthesia was induced with $2.5 \mathrm{mg} \cdot \mathrm{kg}^{-1}$ propofol and maintained with $\mathrm{O}_{2} 100 \%$ and sevoflurane $1-2 \%$. Muscle relaxation was with $0.5 \mathrm{mg} \cdot \mathrm{kg}^{-1}$ atracurium. Two experienced ILM users inserted/fixed the ILM according to the manufacturer's instructions. ${ }^{6} \mathrm{~A}$ size \#5 ILM was used for all anesthetised patients and cadavers. ${ }^{7,8}$ The number of insertion attempts required was recorded. A failed attempt was defined as removal of the device from the mouth. The time between placement of the device in the mouth to cuff inflation was recorded (insertion time). The pilot balloon was attached via a three-way tap to a $10-\mathrm{ml}$ syringe and a calibrated pressure transducer with an accuracy of $5 \%$. The intracuff pressure was reduced to $-55 \mathrm{~cm} \mathrm{H}_{2} \mathrm{O}$ in vitro. The OLP, in-vipo intracuff pressure and fibreoptic position were documented at zero volume with the cuff fully evacuated and after each additional $10 \mathrm{ml}$ air up to 40 $\mathrm{ml}$. The maximum allowed OLP was $40 \mathrm{~cm} \mathrm{H}_{2} \mathrm{O}$. The anatomical position of the ILM was determined fibreoptically using the following scoring system: 4 , only vocal cords visible; 3 , vocal cords plus posterior epiglottis; 2 , vocal cords plus anterior epiglottis; $1=$ vocal cords not seen. Measurements were made in the supine position with the head-neck in the neutral position and the occiput on a firm pillow. The OLP was measured by closing the expiratory valve of the circle system at a fixed gas flow of $3 \mathrm{~L} \cdot \mathrm{min}^{-1}$, and noting the airway pressure at which the dial on the aneroid manometer reached equilibrium. ${ }^{9}$

The intracuff pressure was adjusted to $60 \mathrm{~cm} \mathrm{H}_{2} \mathrm{O}$ and fibreoptic guided intubation with a lubricated 7.0 mm ID tracheal tube (Lo-Contur, Mallinckrot Medical, Athlone, Ireland) was attempted. The tracheal tube and fibreoptic scope (external diameter 3.6 $\mathrm{mm}$ ) were advanced together along the ILM tube until the epiglottic elevator bar opened. The fibreoptic scope was then passed into the trachea and the tracheal tube advanced over the fibreoptic scope into position. Successful intubation was determined with the fibreoptic scope. The number of intubation attempts required was recorded. A failed attempt was defined as failure to pass the fibreoptic scope into the trachea within one minute or failure of the tracheal tube to advance smoothly into the trachea. The time between placement of the fibreoptic scope and tracheal tube in the ILM tube and successful intubation was recorded (intubation time). The position of the ILM was not adjusted prior to the first intubation attempt, but adjustments were permitted for subsequent attempts (maximum of three allowed).

Data were collected by two unblinded trained observers. Statistical analysis was with paired t test, Friedman's two-way analysis of variance and Chi squared test. Data are presented as mean $\pm S D$ unless otherwise stated. Significance was taken as $P<0.05$.

\section{Results}

Demographic data, first time insertion and intubation success rates, and insertion and intubation times are presented in Table I. One cadaver required two insertion attempts. The reason for insertion failure was difficulty in rotating the ILM into the pharynx and this was corrected by adjusting the position of the head-neck. Two anesthetised patients required two intubation attempts and one cadaver required two intubation attempts. The reason for intubation failure in all cases was difficulty in advancing the tracheal tube smoothly and this was corrected by positional adjustments of the ILM. There were no differences in OLP, in-vivo intracuff pressure or fibreoptic position between groups (Table II). OLP in anes- 
thetised patients and cadavers increased with increasing intracuff volume from $0-10 \mathrm{ml}, 10-20 \mathrm{ml}, 20-30 \mathrm{ml}$ (all: $P<0.05)$ and was unchanged from 30 to $40 \mathrm{ml}$.

\section{Discussion}

Our data show that the performance of the ILM in cadavers is similar to that in paralysed anestherised patients. This suggest that cadavers may be useful for training when access to anesthetised patients is limited and as an investigative tool when the use of anesthetised or unconscious patients would be inappropriate. An advantage of cadavers as an educational model is that each cadaver may be used on multiple occasions without concerns for tissue trauma. Compared with the anesthetised patient, cadavers have a lower temperature, more rigid musculature and do not undergo spontaneous or positive pressure ventilation. We had no problems with mouth opening or head-neck movement in cadavers, despite the increased stiffness. The finding that in-vivo intracuff pressure and OLP were similar suggests that pharyngeal compliance was also similar. This may be related to the freshness of the cadavers and age-related differences in the rigidity of the pharyngeal tissues. We speculate that the effects of rigor mortis on increas-

TABLE I Demographic data, first time insertion and intubation success rates, and insertion and intubation times.

Data are mean $\pm S D$.

\begin{tabular}{llll}
\hline & $\begin{array}{l}\text { Anesthetised } \\
\text { Patients }\end{array}$ & Cadapers & $P$ \\
\hline Age; yr & $42 \pm 16$ & $77 \pm 8$ & $<0.0001$ \\
Height; cm & $168 \pm 9$ & $166 \pm 8$ & NS \\
Weight; kg & $67 \pm 12$ & $72 \pm 10$ & NS \\
Male:female ratio & $10: 10$ & $10: 10$ & NS \\
First time insertion & & & \\
success rate; n & $20 / 20(100 \%)$ & $19 / 20(95 \%)$ & NS \\
Insertion time; sec & $13 \pm 8$ & $14 \pm 4$ & NS \\
First time intubation & & & \\
success rate; n & $18 / 20(90 \%)$ & $19 / 20(95 \%)$ & NS \\
Intubation time; sec & $32 \pm 11$ & $27 \pm 15$ & NS \\
\hline
\end{tabular}

ing pharyngeal rigidity are offset by lower pharyngeal rigidity in the elderly patient. Although lung compliance would be lower in cadavers, it is unlikely that this would have affected any of the measured variables.

We conclude that the performance of the ILM is similar for fresh cadavers and paralysed anesthetised patients. This suggests that the fresh cadaver is a suitable model for training and research.

\section{References}

1 Brain AIJ, Verghese C, Addy EV, Kapila A. The intubating laryngeal mask. I: development of a new device for intubation of the trachea. Br J Anaesth 1997; 79 : 699-703.

2 Brain AIJ, Verghese $C$, Addy EV, Kapila A, Brimacombe $J$. The intubating laryngeal mask. II: a preliminary clinical report of a new means of intubating the trachea. Br J Anaesth 1997; 79: 704-9.

3 Ferson DZ, Brimacombe J, Brain AIJ, Verghese C. The intubating laryngeal mask airway. International Anesthesiology Clinics 1998; 36: 183-209.

4 Brimacombe J, Keller C. Cervical spine instability and the intubating laryngeal mask - a caution (Letter). Anacsth Intensive Care 1999; 26: 708.

5 Branthwaite MA. An unexpected complication of the intubating laryngeal mask. Anaesthesia 1999; 54: 166-7.

6 Brain AIJ. LMA - Fastrach ${ }^{\mathrm{TM}}$ Instruction Manual. The Laryngeal Mask Company Ltd, 1997.

7 Berry AM, Brimacombe J, McManus KF, Goldblatt $M$. An evaluation of the factors influencing selection of the optimal size of laryngeal mask airway in normal adults. Anaesthesia 1998; 53: 565-70.

8 Brimacombe J, Keller C. Laryngeal mask airway size selection in males and female: ease of insertion, oropharyngeal leak pressure, pharyngeal mucosal pressures and anatomical position. Br J Anaesth 1999; 82: 703-7.

9 Keller C, Brimacombe JR, Keller K, Morris $R$. Comparison of four methods for assessing airway sealing pressure with the laryngeal mask airway in adult patients. Br J Anaesth 1999; 82: 286-7.

TABLE II Oropharyngeal leak pressure, in-pivo intracuff pressure and fibreoptic score with increasing cuff volume for paralyzed anesthetised male patients and fresh male cadavers using size $\# 5$ intubating laryngeal mask airway. Data are mean $\pm S D$ (range).

\begin{tabular}{|c|c|c|c|c|c|c|}
\hline \multirow[b]{2}{*}{$\begin{array}{l}\text { Cuff Volume } \\
\text { (ml) }\end{array}$} & \multicolumn{2}{|c|}{ Oropharyngeal leak pressure; $\mathrm{cm} \mathrm{H}_{2} \mathrm{O}$} & \multicolumn{2}{|c|}{ In-vivo intracuff pressure; cm $\mathrm{H}_{2} \mathrm{O}$} & \multicolumn{2}{|c|}{ Fibreoptic score: $4 / 3 / 2 / 1 ; n$} \\
\hline & $\begin{array}{l}\text { Anesthetised } \\
\text { Patients }\end{array}$ & Cadavers & $\begin{array}{l}\text { Anesthetised } \\
\text { Patients }\end{array}$ & Cadavers & $\begin{array}{l}\text { Anesthetised } \\
\text { Patients }\end{array}$ & Cadavers \\
\hline 0 & $15 \pm 4(6-27)$ & $16 \pm 5(7-23)$ & $-6 \pm 9(-20-10)$ & $-6 \pm 10(-31-12)$ & $0 / 0 / 7 / 13$ & $0 / 0 / 7 / 13$ \\
\hline 10 & $27 \pm 6(11-40)$ & $27 \pm 5(12-40)$ & $43 \pm 10(28-59)$ & $48 \pm 11(31-69)$ & $1 / 1 / 10 / 8$ & $0 / 1 / 9 / 10$ \\
\hline 20 & $32 \pm 6(13-40)$ & $33 \pm 6(14-40)$ & $84 \pm 19(60-142)$ & $91 \pm 20(67-148)$ & $1 / 1 / 12 / 6$ & $0 / 1 / 10 / 9$ \\
\hline 30 & $36 \pm 5(26-40)$ & $37 \pm 5(25-40)$ & $144 \pm 33(107-148)$ & $151 \pm 35(163-336)$ & $1 / 2 / 12 / 5$ & $0 / 1 / 12 / 7$ \\
\hline 40 & $36 \pm 5(23-40)$ & $37 \pm 5(24-40)$ & $228 \pm 34(160-317)$ & $239 \pm 38(163-336)$ & $1 / 1 / 12 / 6$ & $0 / 2 / 12 / 6$ \\
\hline
\end{tabular}

Fibreoptic score $4=0$ ly vocal cords visible $3=$ vocal cords plus posterior epiglottis $2=$ vocal cords plus anterior epiglottis $1=v o c a l$ cords not seen 